\title{
STUDY OF HEAT RESISTANCE OF EPOXY MATRIX MODIFIED BY PHTHALIMIDE FOR PROTECTION OF VEHICLES
}

\author{
Andriy Buketov'; Alexander Sharko ${ }^{1}$; Tatiana Cherniavska ${ }^{1}$; \\ Tatiana Ivchenko'; Vitaly Yatsyuk ${ }^{2}$; Ihor Okipnyi ${ }^{3}$ \\ ${ }^{1}$ Kherson State Maritime Academy, Kherson, Ukraine \\ ${ }^{2}$ Ternopil Scientific Research Forensic Center of the Ministry of Internal Affairs \\ of Ukraine, Ternopil, Ukraine \\ ${ }^{3}$ Ternopil Ivan Puluj National Technical University, Ternopil, Ukraine
}

Summary. The perspectives of using new modified polymer-based materials for the restoration of vehicle parts are substantiated in this article. The use of binders based on epoxy diane oligomers is proved to be promising in the formation of anti-corrosion coatings. To improve the properties of epoxy matrices at the preliminary stage of their formation, active additives are introduced. The use of a phthalimide modifier, which contains functional groups active before interfacial interaction, is proved to be promising as well.

An epoxy diane oligomer is selected as the binder's main component in the formation of composites. The hardener polyethylene polyamine is used for crosslinking the epoxy compositions. It allows to harden materials at room temperatures. The choice of a phthalimide modifier for the improvement of thermophysical properties of the developed materials is substanciated.

Heat resistance (according to Martens), glass transition temperature and thermal coefficient of linear expansion of modified epoxy composites are studied. To form a composite material or protective coating with improved thermophysical properties, the modifier phthalimide in the amount of $q=0.25 \ldots 0.50$ pts. wt. at $q=100$ pts. wt. of epoxy oligomer ED-20 should be introduced into the epoxy binder. Based on the tests of thermophysical properties of phthalimide-modified materials, the allowable temperature limits, at which it is possible to use the developed composites, are found. temperature.

Key words: epoxy composite, heat resistance, thermal coefficient of linear expansion, glass transition

Statement of the problem. Due to the significant autonomy of navigation, the vessels of the modern flotilla are marked not only by the reliability of the equipment parts, but also by their maintainability, including in sail conditions. In this regard, the use of polymer composite materials $(\mathrm{CM})$ and protective coatings based on them is relevant. Despite the wide range of currently known polymer composites, the most common are anti-corrosion adhesives based on epoxy oligomers. In the formation of such materials at the stage of crosslinking, various additives are introduced into the binder. Therefore, the degree of gelation of heterogeneous systems increases, leading to the improvement of their properties [1-4]. It should be noted that modern ships are affected by the dynamics of climatic loads due to operation in different time zones in a short period of time. Thus, the operation of both hulls and machines and mechanisms under the influence of operating temperatures is considered. The protective anti-corrosion coatings, which are exposed to both dynamic mechanical and thermal loads and external climatic factors, are found to be the most damageable. Therefore, the study and analysis of thermophysical properties of polymer coatings under different operating conditions, including under the influence of the thermal field, is a challenge of modern materials science. 
Analyses of available investigations and publications. The authors [5-9] proved that the use of binders based on epoxy diane oligomers is promising in the formation of anticorrosion coatings. To improve the properties of epoxy matrices at the preliminary stage of their formation, active additives are introduced. The use of modifiers that contain active to interfacial interaction functional groups is promising as well. The introduction $[5,6]$ of homeopathic content of such additives as 4,4'-methylenebis (4,1-phenylene) bis (N, Ndiethyldithiocarbamate), 2,4-diaminoazobenzene-4'-carboxylic acid, 4,4'-methylenebis (2methoxyaniline), paraaminoazobenzene, benzene-1,3-diamine, etc. is known to provide a significant improvement in the adhesive and cohesive properties of CM and protective coatings based on them. However, the use of phthalimide as a modifier for the epoxy matrix is interesting from a scientific and practical point of view. Such a modifier contains carbonyl and nitrogencontaining groups. In this case, we should expect additional interaction with macromolecules of the epoxy oligomer. This allows improving the cohesive and, as a consequence, thermophysical properties of anti-corrosion adhesives. The use of composites will increase the reliability and serviceability of vehicles.

Objective of the paper - is to study the influence of phthalimide content on the thermophysical properties of epoxy composites in order to increase the maintainability and service life of ships.

Materials and methods of research. The epoxy diane oligomer ED-20 (GOST 1058784 ) is selected as the main component for the binder in the formation of epoxy CM. The oligomer is characterized by high adhesive and cohesive strength, low shrinkage and manufacturability when applied to the surface of a complex profile.

Phthalimide (other names: o-phthalic acid imide or isoindoline-1,3-dione) was used as a modifier. The modifier was introduced into the binder with a content from 0.10 to 2.00 pts.wt. per 100 pts. wt. of epoxy oligomer ED-20 (hereinafter referred to as pts. wt. are given per 100 pts. wt. of epoxy oligomer ED-20). Molecular formula of the modifier: $\mathrm{C}_{8} \mathrm{H}_{5} \mathrm{NO}_{2}$. The molar mass of phthalimide is $147.13 \mathrm{~g} / \mathrm{mol}$. Density $-1.47 \mathrm{~g} / \mathrm{cm}^{3}$. Thermal properties: melting point $-238^{\circ} \mathrm{C}$, boiling point $-336^{\circ} \mathrm{C}$. Molecular heat capacity is $1.21 \mathrm{~J} /(\mathrm{mol} \cdot \mathrm{K})$. Phthalimide possesses the properties of dicarboxylic acids: it easily hydrolyzes under the action of $25 \%$ aqueous $\mathrm{NaOH}$ solution with the formation of phthalamic acid; alkynation of alcohols produces $\mathrm{N}$-alkyl-substituted acids; amonolysis leads to the formation of phthalic acid diamide. The modifier is soluble in water and polar organic solvents.

Epoxy composites were formed based on the following technology [5, 6]: the heating of resin to a temperature $T=353 \pm 2 \mathrm{~K}$ and holding at a given temperature for a time $\tau=20 \pm 0.1 \mathrm{~min}$; hydrodynamic combination of oligomer and filler particles over time $\tau=10 \pm 0.1 \mathrm{~min}$; ultrasonic treatment of the composition for a time $\tau=1.5 \pm 0.1 \mathrm{~min}$; cooling the composition to room temperature over time $\tau=60 \pm 5 \mathrm{~min}$; introduction of the hardener and combination of the composition components for a time $\tau=5 \pm 0.1 \mathrm{~min}$. CM were hardened according to the mode: formation of samples and their aging over time $\tau=12.0 \pm 0.1$ hours at a temperature $T=293 \pm 2 \mathrm{~K}$, heating at a rate $v=3 \mathrm{~K} / \mathrm{min}$ to a temperature $T=393 \pm 2 \mathrm{~K}$, aging for a time $\tau=2.0 \pm 0.05$ hours, slow cooling to a temperature $T=293 \pm 2 \mathrm{~K}$. In order to stabilize the structural processes in the composite, samples were kept for a time $\tau=24$ hours in air at a temperature $T=293 \pm 2 \mathrm{~K}$. Then, the experimental tests were conducted.

The thermal coefficient of linear expansion (TCLR) and heat resistance (HR) of CM were studied in this work. Heat resistance (according to Martens) of CM was determined in accordance with GOST 21341-75. The thermal coefficient of linear expansion (TCLR) of materials was calculated applying the influence curve of relative deformation due to temperature. The relative deformation was determined by the change in the length of the sample with increasing temperature (GOST 15173-70). 
Research results and their discussion. The thermophysical properties were studied in the complex. Based on the original and modified matrices, heat resistance (according to Martens), glass transition temperature and thermal coefficient of linear expansion (TCLR) of the samples were determined in parallel. The heat resistance of the original unmodified epoxy matrix is experimentally found to be $T=341 \mathrm{~K}$ (Fig. 1). The introduction of the modifier at low content (in the amount of $\mathrm{q}=0.25 \ldots 0.50 \mathrm{pts}$. wt.) leads to a significant increase in heat resistance of materials. Heat resistance (Fig. 1) compared with the original matrix increases from $T=341 \mathrm{~K}$ to $T=354 \ldots 356 \mathrm{~K}$. Further increase in the additive content does not significantly reduce the heat resistance of $\mathrm{CM}$; and the content of phthalimide in the amount of $\mathrm{q}=2.00$ pts. wt. in the epoxy matrix forms a material with heat resistance $T=352 \mathrm{~K}$.

In our opinion, the improvement of thermophysical properties of modified CM is caused by a decrease in the intermolecular distribution of macromolecules in homogeneous systems due to an increase in the crosslinking density of the spatial grid of modified matrices. This is due to the interaction in the gelation of composites of the active groups of the modifier with the functional side groups of the epoxy oligomer. Therefore, the cohesive properties of the developed CM are improved, which is in good agreement with [10,11].

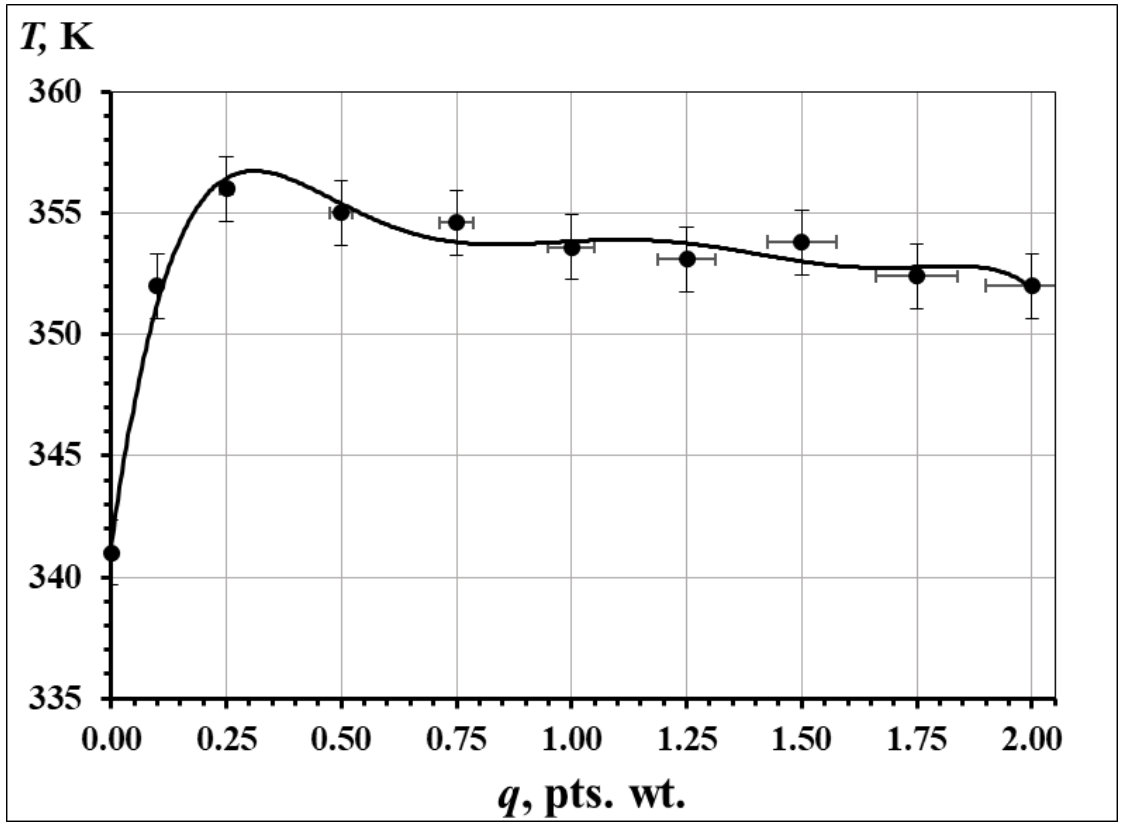

Figure 1. Dependence of heat resistance (according to Martens) of CM on the content of the phthalimide modifier

Further, the dynamics of the glass transition temperature of the modified CM depending on the content of phthalimide was analyzed. The glass transition temperature of the epoxy matrix (Fig. 2) is proved to be $T_{c}=327 \mathrm{~K}$. The introduction of additives at homeopathic content (in the amount of $q=0.25 \ldots 0.50$ pts. wt.) leads to a slight increase in the glass transition temperature of the modified matrices (the latter increases from $T_{c}=327 \mathrm{~K}$ to $\left.T_{c}=329 \ldots 331 \mathrm{~K}\right)$. However, the introduction of the phthalimide modifier in the amount of $q=2.00$ pts. wt. provides the formation of a material with the glass transition temperature $T_{c}=336 \mathrm{~K}$, which is the highest among the entire range of materials under study. The obtained results of the study of changes in heat resistance and glass transition temperature of $\mathrm{CM}$ depending on the content of the modifier are not completely correlated. The best indicators of 
$\mathrm{CM}$ heat resistance were observed for composites containing an additive in the amount of $q=$ $0.25 \ldots 0.50$ pts. wt.; and the material with a modifier with a content of $q=2.00$ pts. wt. is marked by the highest values of $T_{c}$. Based on the above, the thermal coefficient of linear expansion of epoxy composites in different temperature ranges of tests was additionally studied.

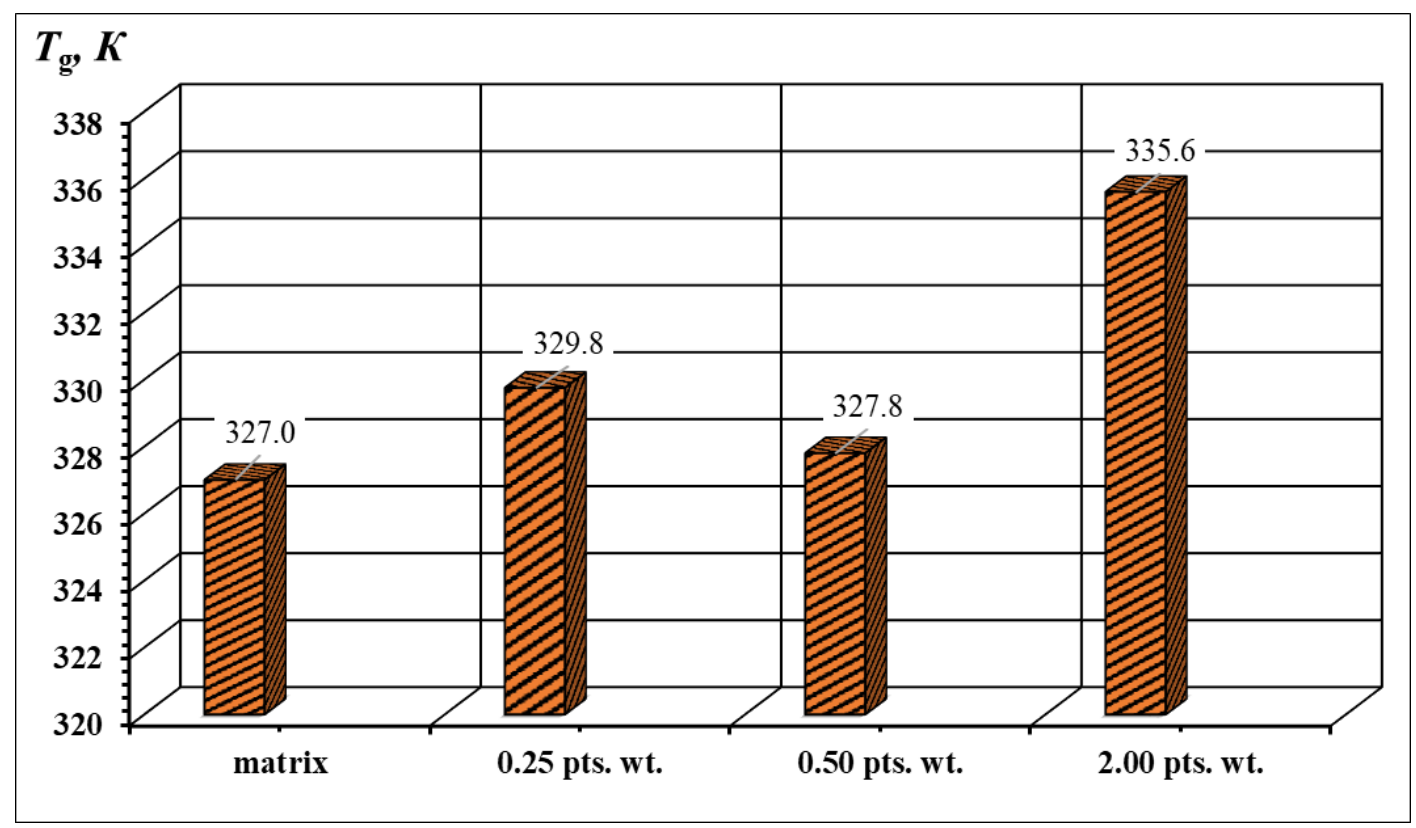

Figure 2. Dependence of CM glass transition temperature on the content of phthalimide modifier

In the range of temperature tests $\Delta T=303 \ldots 323 \mathrm{~K}$, TCLR of the original matrix was experimentally found to be $\alpha=6.3 \times 10^{-5} \mathrm{~K}^{-1}$ (Fig. 3, Table 1 ). The introduction of the modifier reduces the TCLR of materials by 2.3... 2.6 times, while the TCLR indexes decrease to $\alpha=(2.4 \ldots 2.7) \times 10^{-5} \mathrm{~K}^{-1}$. A similar pattern was observed in the study of TCLR samples in the temperature range $\Delta T=303 \ldots 373 \mathrm{~K}$. The introduction of phthalamide regardless of the concentration leads to a decrease in TCLR CM from $\alpha=6.8 \times 10^{-5} \mathrm{~K}^{-1}$ (for epoxy matrix) to $\alpha=(2.8 \ldots 2.9) \times 10^{-5} \mathrm{~K}^{-1}$. This indicates a significant effect of the additive on improving the thermophysical properties of materials that operate at higher temperatures. It is important to analyze the results of the study of CM in the temperature range that is higher than the glass transition temperature of composites. The range of temperature tests is $\Delta T=303 \ldots 423 \mathrm{~K}$, TCLR of the original matrix is $\alpha=9.9 \times 10^{-5} \mathrm{~K}^{-1}$ (Table 1). The maximum decrease in TCLR was observed in this temperature range for samples with a modifier content in the amount of $q=0.25 \ldots 0.50$ pts. wt. For such materials, TCLR is $\alpha=(4.4 \ldots 4.8) \times 10^{-5} \mathrm{~K}^{-1}$. Increase in the content of the modifier to $q=2.00$ pts. wt. leads to an increase in TCLR materials to $\alpha=5.3 \times 10^{-5} \mathrm{~K}^{-1}$.

The results of the study of TCLR material in the temperature range $\Delta T=303 \ldots 473 \mathrm{~K}$ revealed the following. TCLR of the original and modified matrices does not differ significantly, since the values are in the range $-\alpha=(10.0 \ldots 11.1) \times 10^{-5} \mathrm{~K}^{-1}$. This indicates the destruction of physical bonds at such temperatures in both the original and modified materials, which is in good agreement with Sperling's work [12].

Based on studies of the thermophysical properties of composites in the complex, it can be stated that the modifier significantly affects the structure and characteristics of materials. The 
content of the phthalimide additive in the amount of $q=0.25 \ldots 0.50$ pts. wt. per 100 pts. wt. of epoxy oligomer ED-20 is considered optimal.

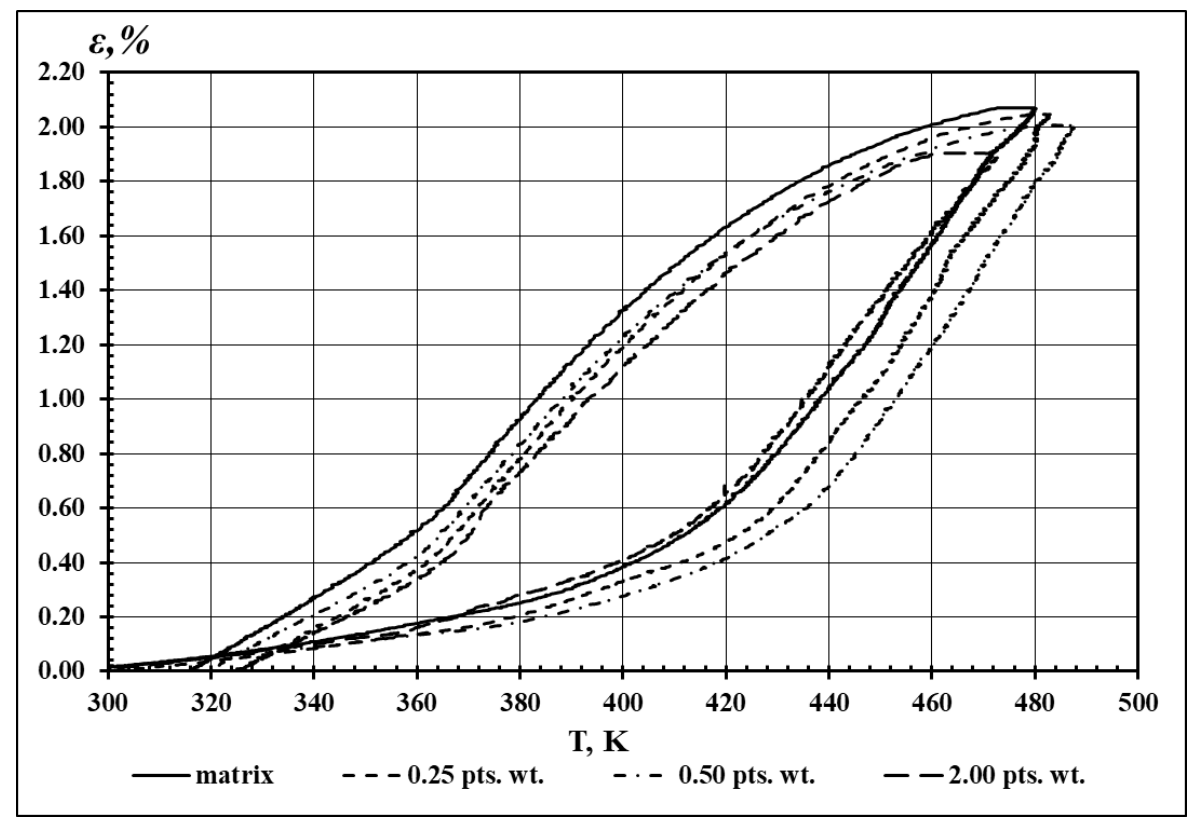

Figure 3. Dilatometric curves of CM with different content of phthalimide modifier

Table 1

Thermal coefficient of linear expansion (TCLR) of CM at different temperature ranges of the study

\begin{tabular}{|c|c|c|c|c|c|}
\hline \multirow{2}{*}{ № } & \multirow{2}{*}{$\begin{array}{c}\text { Filler content, } \\
q, \text { pts.wt. }\end{array}$} & \multicolumn{4}{|c|}{ Thermal coefficient of linear expansion, } \\
& & \multicolumn{4}{|c|}{ Test temperature ranges, $\Delta T, \mathrm{~K}$} \\
\cline { 2 - 6 } & & $303 \ldots 323$ & $303 \ldots 373$ & $303 \ldots 423$ & $303 \ldots 473$ \\
\hline 1 & matrix & 6.3 & 6.8 & 9.9 & 10.9 \\
\hline 2 & 0.25 & 2.6 & 2.8 & 4.4 & 10.4 \\
\hline 3 & 0.50 & 2.4 & 2.8 & 4.8 & 10.0 \\
\hline 4 & 2.00 & 2.7 & 2.9 & 5.3 & 11.1 \\
\hline
\end{tabular}

To confirm the above tests, CM was additionally examined by IR spectroscopy. The spectra of the original matrix and CM with the content of the modifier in the amount of $q=0.50$ pts. wt. (Fig. 4) were analysed. The absorption bands available on the spectra of the matrix $2873.94 \mathrm{~cm}^{-1}$ and $918.12 \mathrm{~cm}^{-1}$ are characteristic for the valence vibrations of the epoxy ring. It should be noted that the absorption band at the wave number $2873.94 \mathrm{~cm}^{-1}$ can also characterize the valence oscillations $-\mathrm{CH}_{2}$. The absorption band at $918.12 \mathrm{~cm}^{-1}$ is absent in the spectrum of the composite, and the absorption band at $2873.94 \mathrm{~cm}^{-1}$ is shifted to the band detected at a wave number of $2870.08 \mathrm{~cm}^{-1}$ (Table 2.). The displacement of the absorption band, which characterizes the presence of hydroxyl groups, from $1049.28 \mathrm{~cm}^{-1}$ to $1037.70 \mathrm{~cm}^{-1}$ is found. This indicates the interaction of the epoxy groups of the binder with the active groups of the modifier.

Intense symmetric and asymmetric valence oscillations of the $-\mathrm{CH}_{2}$ groups were observed at $2966.52 \mathrm{~cm}^{-1}$ and $2873.94 \mathrm{~cm}^{-1}$, respectively. At the same time, the corresponding deformation modes look like less intense absorption at $1454.33 \mathrm{~cm}^{-1}$. The $\mathrm{CH}_{2}$ groups could 
form part of the basic polymer network, and the carbonyl group is part of the ester bond that connects the active centers of the filler with the main chain of macromolecules. In addition, in the CM spectrum, the valence fluctuations are absent at wave numbers $1126.43 \mathrm{~cm}^{-1}, 2542.18 \mathrm{~cm}^{-1}$ and $3417.86 \mathrm{~cm}^{-1}$, which correspond to the deformation oscillations $\mathrm{C}-\mathrm{O}-\mathrm{H},-\mathrm{OH}-$ valence oscillations and $-\mathrm{CH}-$ valence oscillations, respectively. The main difference between the spectra is observed in the site of the absorption bands corresponding to $\mathrm{C}-\mathrm{H}$ tensile oscillations $\left(2700 \ldots 3100 \mathrm{~cm}^{-1}\right)$ and aromatic $\mathrm{C}-\mathrm{H}$ deformation oscillations $(700 \ldots$ $900 \mathrm{~cm}^{-1}$ ). The intense absorption band at $3035.96 \mathrm{~cm}^{-1}$ indicates that the aromatic rings are substituted selectively. Site analysis at $700 \ldots 900 \mathrm{~cm}^{-1}$ also provides information on the substitution of the aromatic ring. The intensity of the absorption bands decreases at $810.10 \mathrm{~cm}^{-1}$ and $840.96 \mathrm{~cm}^{-1}$ on the CM spectrum at a content of 0.50 pts. wt. Of the filler with the subsequent formation of a wide absorption band at $829.39 \mathrm{~cm}^{-1}$.

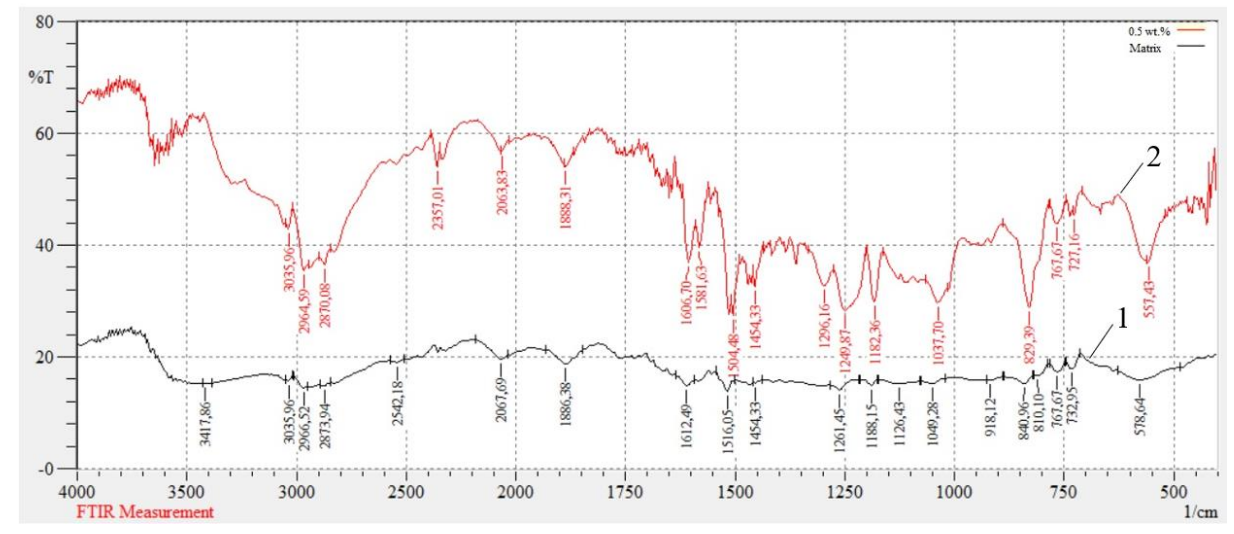

Figure 4. IR spectra of materials under study: 1 - epoxy matrix; $2-\mathrm{CM}$ with a content of 0.50 pts. wt. of the modifier

Table 2

Spectral characteristics of CM

\begin{tabular}{|c|c|c|c|c|}
\hline Band characteristics & \multicolumn{2}{|c|}{ Matrix } & \multicolumn{2}{|c|}{$\begin{array}{l}\mathrm{CM} \text { at a contant of } \\
0.50 \text { pts.wt. of the } \\
\text { modifier }\end{array}$} \\
\hline Group & $\begin{array}{c}v, \\
\mathrm{CM}^{-1}\end{array}$ & $\begin{array}{l}\mathrm{T}, \\
\%\end{array}$ & $\begin{array}{c}v, \\
\mathrm{~cm}^{-1}\end{array}$ & $\begin{array}{l}\mathrm{T}, \\
\%\end{array}$ \\
\hline 1 & 2 & 3 & 4 & 5 \\
\hline$-\mathrm{C}-\mathrm{H}-$ oscillations in the benzene ring & 578.64 & 15.918 & 557.43 & 36.92 \\
\hline $\begin{array}{l}\text { pendulum -CH- oscillations, -NH- oscillations, - } \\
\mathrm{NH}_{2} \text { oscillations of the primary amino group }\end{array}$ & 732.95 & 17.88 & 727.16 & 45.44 \\
\hline $\begin{array}{l}\text { pendulum -CH- oscillations, -NH- oscillations, - } \\
\mathrm{NH}_{2} \text { oscillations of the primary amino group }\end{array}$ & 767.67 & 17.32 & 767.67 & 43.81 \\
\hline \multirow{3}{*}{$\begin{array}{l}\text { Oscillations of a para-substituted aromatic ring of } \\
\text { benzene }\end{array}$} & 810.10 & 16.63 & - & - \\
\hline & - & - & 829.39 & 28.84 \\
\hline & 840.96 & 15.18 & - & - \\
\hline valence oscillations of the epoxy ring & 918.12 & 15.85 & - & - \\
\hline secondary hydroxyl groups & 1049.28 & 15.20 & 1037.70 & 29.78 \\
\hline deformation oscillations C-O-H & 1126.43 & 15.17 & - & - \\
\hline $\begin{array}{l}\text { valence oscillations of -C-C-, -C-N-, -C-O- } \\
\text { groups }\end{array}$ & 1188.15 & 14.94 & 1182.36 & 29.83 \\
\hline
\end{tabular}


(to be continued)

\begin{tabular}{|c|c|c|c|c|}
\hline 1 & 2 & 3 & 4 & 5 \\
\hline $\begin{array}{l}\text { symmetric and asymmetric valence oscillations - } \\
\mathrm{CH}_{2}\end{array}$ & 1454.33 & 15.26 & 1454.33 & 32.58 \\
\hline $\begin{array}{l}\text { Oscillations of the benzene ring, } \mathrm{C}=\mathrm{C} \text { valence } \\
\text { oscillations of the aromatic ring group }\end{array}$ & 1516.05 & 13.83 & 1504.48 & 27.38 \\
\hline $\mathrm{C}=\mathrm{O}$ valence oscillations & - & - & 1581.63 & 39.58 \\
\hline $\mathrm{C}=\mathrm{O}$ valence oscillations & 1612.49 & 14.77 & 1606.70 & 36.98 \\
\hline oscillations of triple $\mathrm{C} \equiv \mathrm{C}, \mathrm{C} \equiv \mathrm{N}$-groups & 2067.69 & 19.53 & 2063.83 & 56.76 \\
\hline valence oscillations of the epoxy ring & 2873.94 & 14.85 & 2870.08 & 36.55 \\
\hline $\begin{array}{l}-\mathrm{CH} \text { valence oscillations, symmetric and } \\
\text { asymmetric valence oscillations }-\mathrm{CH}_{2}\end{array}$ & 2966.52 & 14.42 & 2964.59 & 35.38 \\
\hline $\begin{array}{l}\text { Oscillations of methylene and methyl groups of the } \\
\text { oxirane cycle, valence oscillations - } \mathrm{CH} \text { groups of } \\
\text { aromatic cycles }\end{array}$ & 3035.96 & 15.75 & 3035.96 & 42.97 \\
\hline $\begin{array}{l}-\mathrm{OH}-\text { valence oscillations, }-\mathrm{CH}-\text { valence } \\
\text { oscillations }\end{array}$ & 3417.86 & 15.17 & - & - \\
\hline
\end{tabular}

Conclusions. Based on the research results of the thermophysical properties of composites with consideration of the content of the phthalimide modifier, the conclusions are made:

1. For the formation of a composite material or protective coating with improved thermophysical properties in the epoxy binder, it is advisable to introduce the modifier phthalimide in the amount of $q=0.25 \ldots 0.50$ pts. wt. at $q=100$ pts. wt. of epoxy oligomer ED20. In this case, materials are formed in which, compared with the unmodified matrix, the heat resistance increases from $T=341 \mathrm{~K}$ to $T=354 \ldots 356 \mathrm{~K}$. The improvement of cohesive and, as a consequence, thermophysical properties of modified matrices are caused by the increase in the crosslinking density of the spatial grid of materials. This is due to the interaction in the gelation of composites of the active groups of the modifier with the functional side groups of the epoxy oligomer, which leads to improved properties of the developed composites.

2. The modification of the epoxy binder phthalimide in the amount of $q=2.00$ pts. wt. is substantiated to provide the maximum increase in the glass transition temperature of the material from $T_{c}=327 \mathrm{~K}$ (for the original epoxy matrix) to $T_{c}=336 \mathrm{~K}$. Composites containing an additive in the amount of $q=0.25 \ldots 0.50$ pts. wt. possess the best heat resistance indexes, and a material with a modifier with a content of $q=2.00$ pts. wt. are marked with the highest $T_{c}$ indicators. Therefore, the thermal coefficient of linear expansion of epoxy composites in different temperature ranges of tests was additionally studied.

3. In the range of temperature tests $\Delta T=303 \ldots 323 \mathrm{~K}$, the introduction of the phthalimide modifier in the amount of $q=0.25 \ldots 0.50 \mathrm{pts}$. wt. was proved to cause a decrease in TCLR materials by $2.3 \ldots 2.6$ times. Additionally, it was found that in the temperature range $\Delta T=303 \ldots 423 \mathrm{~K}$, which are higher than the glass transition temperature of materials, the lowest values of TCLR are characterized by the same composites with a modifier content in the amount of $q=0.25 \ldots 0.50$ pts. wt. Besides, a material is developed, whose TCLR is $2.1 \ldots 2.3$ times smaller compared to the epoxy matrix (TCLR decreases from $\alpha=9.9 \times 10^{-5} \mathrm{~K}^{-1}$ to $\alpha=$ $\left.(4.4 \ldots 4.8) \times 10^{-5} \mathrm{~K}^{-1}\right)$. 


\section{References}

1. Taher A. A. Fyzyko-khymyya polymerov. M.: Nauchnyy myr, 2007. 573 p.

2. Vilens'kyy V. O., Demchenko V. L., Kercha YU. YU., Shut M. I. Doslidzhennya termomekhanichnykh ta teplofizychnykh vlastyvostey nanokompozytiv na osnovi poliepoksydu ta dyspersnykh napovnyuvachiv riznoyi pryrody. Fizyka kondensovanykh vysokomolekulyarnykh system. 2009. Vyp. 13. P. 18-23.

3. Kocherhyn YU. S., Kulyk T. A., Hryhorenko T. Y. Kleevye kompozytsyy na osnove modyfytsyrovannykh époksydnykh smol. Plastycheskye massy. 2005. No. 10. P. 9-16.

4. Voronkov A. H., Yartsev V. P. Époksydnye polymerrastvory dlya remonta y zashchyty stroytel'nykh yzdelyy y konstruktsyy: uchebnoe posobye. Tambov: Yzd-vo Tamb. hos. tekhn. un-ta, 2006. 92 p.

5. Buketov A. V., Nehrutsa R. YU., Yatsyuk V. M. Vplyv modyfikatora 2,4-dyaminoazobenzol-4'karbonovoyi kysloty na adheziyni vlastyvosti ta zalyshkovi napruzhennya zakhysnykh polimernykh pokryttiv. Naukovi notatky. Luts'k: LNTU. Vyp. 65. 2019. P. 30-38.

6. Buketov A. V., Smetankyn S. A. Vlyyanye modyfykatora 4,4-sul'fonylbys (4,1-fenylen)bys(n,ndyétyldytyokarbamata) na adhezyonnye svoystva époksydnoy matrytsy. Mekhanyka kompozytsyonnykh materyalov y konstruktsyy. 2018. Vol. 24. No. 2. P. 242-265.

7. Buketov A. V., Brayilo M. V., Yakushchenko S. V., Yatsyuk V. M. Rozroblennya epoksypoliefirnoyi matrytsi z polipshenymy adheziynymy ta fizyko-mekhanichnymy vlastyvostyamy zi zastosuvannyam izotsianatnoho modyfikatora. Fizyko-khimichna mekhanika materialiv. 2019. 55. No. 2. P. 31-36. https://doi.org/10.1007/s11003-019-00284-1

8. Buketov A. V., Stukhlyak P. D., Levyts'kyy V. V., Dolhov M. A. Doslidzhennya epoksykompozytiv, shcho mistyat' modyfikovani olihomeramy napovnyuvachi. Visnyk TDTU. 2004. No. 2. P. 52-59.

9. Buketov A. V., Stukhlyak P. D., Dolhov M. A. Doslidzhennya povedinky epoksykompozytnykh pokryttiv $\mathrm{v}$ umovakh napruzheno-deformovanoho stanu pislya yikh UF-oprominennya i mahnitnoyi obrobky. Visnyk TDTU.2004. No. 4. P. 36-45.

10. Stukhlyak P. D. Antifriction and adhesive properties of coatings of thermosetting plastics modified with thermoplastic polymers. Soviet Journal of Friction and Wear (English translation of Trenie i Iznos), 1986, 7(1), pp. 138-141.

11. Stukhlyak P. D., Bliznets M. M. Wear resistance of epoxyfuran composites modified with polyvinyl alcohol. Soviet Journal of Friction and Wear (English translation of Trenie i Iznos), 1987, 8(3), pp. 122124.

12. Sperling L. Vzaimopronikayuschie polimernyie setki $\mathrm{i}$ analogichnyie materialyi, per. $\mathrm{s}$ angl. N. V. Kovyirshinoy. M.: Mir, 1984. 327 p.

\section{Список використаної літератури}

1. Тагер А. А. Физико-химия полимеров. М.: Научный мир, 2007. 573 с.

2. Віленський В. О., Демченко В. Л., Керча Ю. Ю., Шут М. І. Дослідження термомеханічних та теплофізичних властивостей нанокомпозитів на основі поліепоксиду та дисперсних наповнювачів різної природи. Фізика конденсованих високомолекулярних систем. 2009. Вип. 13. С. 18-23.

3. Кочергин Ю. С., Кулик Т. А., Григоренко Т. И. Клеевые композиции на основе модифицированных эпоксидных смол. Пластические массы. 2005. № 10. С. 9-16.

4. Воронков А. Г., Ярцев В. П. Эпоксидные полимеррастворы для ремонта и защиты строительных изделий и конструкций: учебное пособие. Тамбов: Изд-во Тамб. гос. техн. ун-та, 2006. 92 с.

5. Букетов А. В., Негруца Р. Ю., Яцюк В. М. Вплив модифікатора 2,4-диаміноазобензол-4'- карбонової кислоти на адгезійні властивості та залишкові напруження захисних полімерних покриттів. Наукові нотатки. Вип. 65. 2019. С. 30-38.

6. Букетов А. В., Сметанкин С. А. Влияние модификатора 4,4-сульфонилбис (4,1-фенилен)бис(n,nдиэтилдитиокарбамата) на адгезионные свойства эпоксидной матрицы. Механика композиционных материалов и конструкций. 2018. Т. 24. № 2. С. 242-265.

7. Букетов А. В., Браїло М. В., Якущенко С. В., Яцюк В. М. Розроблення епоксиполіефірної матриці з поліпшеними адгезійними та фізико-механічними властивостями зі застосуванням ізоціанатного модифікатора. Фізико-хімічна механіка матеріалів. 2019. 55, № 2. С. 31-36. https://doi.org/10.1007/s11003-019-00284-1

8. Букетов А. В., Стухляк П. Д., Левицький В. В., Долгов М. А. Дослідження епоксикомпозитів, що містять модифіковані олігомерами наповнювачі. Вісник ТДТУ. 2004. № 2. С. 52-59.

9. Букетов А. В., Стухляк П. Д., Долгов М. А. Дослідження поведінки епоксикомпозитних покриттів в умовах напружено-деформованого стану після їх УФ-опромінення і магнітної обробки. Вісник ТДТУ. 2004. № 4. С. 36-45.

10. Stukhlyak P. D. Antifriction and adhesive properties of coatings of thermosetting plastics modified with thermoplastic polymers. Soviet Journal of Friction and Wear (English translation of Trenie i Iznos). 1986. 7 (1), pp. 138-141. 
11. Stukhlyak P. D., Bliznets M. M. Wear resistance of epoxyfuran composites modified with polyvinyl alcohol. Soviet Journal of Friction and Wear (English translation of Trenie i Iznos). 1987. 8 (3), pp. 122124.

12. Сперлинг Л. Взаимопроникающие полимерные сетки и аналогичные материалы / пер. с англ. Н. В. Ковыршиной. М.: Мир, 1984. 327 с.

\title{
УДК 667.64:678.026
}

\section{ДОСЛІДЖЕННЯ ТЕПЛОСТІЙКОСТІ МОДИФІКОВАНОЇ ФТАЛІМІДОМ ЕПОКСИДНОЇ МАТРИЦІ ДЛЯ ЗАХИСТУ ЗАСОБІВ ТРАНСПОРТУ}

\author{
Андрій Букетов ${ }^{1}$; Олександр Шарко ${ }^{1}$; Тетяна Чернявська ${ }^{1}$; \\ Тетяна Івченко ${ }^{1}$; Віталій Яцюк²; Ігор Окіпний ${ }^{3}$ \\ ${ }^{1}$ Херсонська державна морська академія, Херсон, Украӥна \\ ${ }^{2}$ Тернопільський науково-дослідний експертно-криміналістичний центр \\ МВС України, Тернопіль, Украӥна \\ ${ }^{3}$ Тернопільський національний технічний університет імені Івана Пулюя, \\ Тернопіль, Україна
}

Резюме. Показано перспективи використання нових модифікованих матеріалів на полімерній основі для відновлення деталей засобів транспорту. Перспективним при формуванні антикорозійних покриттів є використання зв'язувачів на основі епоксидних діанових олігомерів. Для покращення властивостей епоксидни матриць на попередній стадії їх формування вводять активні добавки. Перспективним є застосування модифікатора фталіміду, який містить активні до міжфазової взаємодії функціональні групи. Як основний компонент для зв'язувача при формуванні композитів вибрано епоксидний діановий олітомер. Для зиивання епоксидних композииій використано твердник поліетиленполіамін, щзо затверджує матеріали при кімнатних температурах. Обтрунтовано вибір у вигляді модифікатора фталіміду для поліпшення теплофізичних властивостей розроблених матеріалів.

Досліджено теплостійкість (за Мартенсом), температуру склування й термічний коефіцієнт лінійного розширення модифікованих епоксидних композитів. Встановлено, щзо для формування композитного матеріалу чи захисного покриття з поліпшеними теплофізичними властивостями 6 епоксидний зв'язувач доцільно вводити модифікатор фталімід у кількості $q=0,25 \ldots 0,50$ мас.ч. на $q=100$ мас.ч. епоксидного олігомеру ЕД-20. На основі проведених випробувань теплофізичних властивостей модифікованих фталімідом матеріалів встановлено допустимі межі температури, при яких можливо використовувати розроблені композити.

Ключові слова: епоксидний композит, теплостійкість, термічний коефіцієнт лінійного розширення, температура склування. 